\title{
DIGITALIZACE PERIODIK V ODDĚLENÍ ČASOPISŮ KNIHOVNY NÁRODNÍHO MUZEA V LETECH 2015-2020*
}

\author{
Adam Jaško (PIzeň)
}

\section{Úvod}

Oddělení časopisů Knihovny Národního muzea (dále KNM) se od roku 2016 znovu začalo ucházet o finanční prostředky v dotačním programu VISK $7 .{ }^{1}$ Cílem tohoto projektu je podpora aktivit směřujících $\mathrm{k}$ záchraně dokumentů ohrožených rozpadem kyselého papíru. ${ }^{2}$ Strategie výběru se v KNM orientuje na digitalizaci meziválečného periodického denního tisku, protože je badateli nejžádanější a současně ve velmi špatném fyzickém stavu. Jako první byla započata digitalizace titulu Prager Presse, následovalo meziválečné Rudé právo a v současné době probíhá digitalizace titulu České slovo. V tomto článku osvětlíme, jak digitalizace v oddělení časopisů v roce 2016 začala, s jakými úskalími se setkávala a jakými úspěchy se může pochlubit. Stručně bude zmíněna i digitalizace před rokem 2015.

\section{Digitalizace před rokem 2015}

Digitalizace periodik v oddělení časopisů KNM započala již v roce 2005, kdy bylo zahájeno reformátování titulů Politik ${ }^{3}$ a Correspondenz. ${ }^{4}$ Posledně jmenovaný vycházel v letech 1867-1869 jako náhrada za Politik, který byl v tomto období zastaven. Oproti původnímu plánu zpracovat oba tituly co nejrychleji, podle tehdejších představ řešitelů do dvou let, se digitalizace výrazně protáhla, což bylo způsobeno především nedostatkem financí. Ještě v roce 2007 konstatuje žádost o dotaci z programu VISK 7, že přidělené finanční prostředky $\mathrm{v}$ předchozích dvou letech nebyly dostatečné, což proces digitalizace zpomalilo. Tehdy, ve třetím roce projektu, bylo z celkových cca 180000 stran zpracováno teprve necelých 60000 stran.

Mimo obou výše zmíněných titulů Knihovna Národního muzea digitalizovala podobným způsobem vlastní periodikum
Časopis Společnosti wlastenského museum w Čechách a na něj navazující přjejmenované tituly. ${ }^{5}$

Pravidla dotačního programu v té době vyžadovala, aby se originál nejprve nasnímal na archivní mikrofilm a z něj se poté převáděl do digitální podoby. Později bylo mikrofilmování opuštěno a originální předlohy mohly být skenovány přímo. V té době ještě nebylo vyžadováno, aby se k snímkům připojovaly soubory s textovým přepisem OCR a soubory ALTO (data zobrazující polohu znaků přímo na skenu). Proto jsou v Krameriu Národního muzea ${ }^{6}$ snímky Politiku určené $\mathrm{k}$ prohlížení černobílé a nelze $\mathrm{v}$ nich fulltextově vyhledávat.

Výše zmíněný faktor omezených finančních prostředků se stal důležitým východiskem při plánování digitalizace periodik na úrovni jednotlivých ročníků a poznamenal i strategii při obnovení digitalizace $\mathrm{v}$ roce 2016 a v pozdějších letech.

\section{Obnovení digitalizace v roce 2015}

Po dokončení titulů Politik a Correspondenz digitalizace v oddělení periodik na několik let ustala. Aby nedocházelo k tříštění finančních prostředků na jednotlivé projekty, byl v rámci Knihovny Národního muzea původní př́spěvek pro oddělení časopisů přesměrován do oddělení základní knihovny. Ta v té době prováděla skenování svého lístkového katalogu a finance původně určené pro oddělení časopisů jí pomohly v rychlejším postupu. Oddělení periodik se do programu VISK 7 znovu zapojilo na konci roku 2015, kdy byla podána žádost o dotaci, přičemž ještě na jaře téhož roku bylo rozhodnuto, že oddělením časopisů KNM bude připraven k digitalizaci titul Prager Presse. V důsledku několikaletého přerušení se však nedochovalo žádné know-how, jak periodikum pred digitalizací připravit a na co během ní ze strany knihovny dát pozor.

\footnotetext{
* Autor článku v těchto letech pracoval v oddělení časopisů KNM jako řešitel digitalizace a článek vychází z nabytých poznatků a jeho osobní zkušenosti. ${ }^{1}$ VISK 7. Národní program digitálního zpřistupňování dokumentů ohrožených degradací kyselého papíru - Kramerius [online]. Praha: Národní knihovna, [2015]. [Cit. 5. 11. 2021].

Podrobnějš́i informace dostupné z: https://visk.nkp.cz/visk-7 [cit. 27. 10. 2021].

3 Dostupné z: https://kramerius.nm.cz/unid/uuid:13a0c600-eac6-11dc-8361-000d606f5dc6 [cit. 2. 11. 2021]

${ }^{4}$ Dostupné z: https://kramerius.nm.cz/uuid/uuid:31f992c2-8be4-11e2-a608-00155d069400 [cit. 2. 11. 2021]

5 Dostupné z: https://kramerius.nm.cz/unid/uuid:b6da9cc0-8967-11dd-b6b1-000d606f5dc6 [cit. 2. 11. 2021]

6 Dostupné z: https://kramerius.nm.cz/ [cit. 27. 10. 2021].
} 


\section{Digitalizace titulu Prager Presse}

Myšlenka na založení samotných novin Prager Presse vzešla od T. G. Masaryka a titul si kladl za cíl přinášet kvalitní a objektivní informace $\mathrm{z}$ dění uvnitř mladého československého státu, ale i z celé Evropy. ${ }^{7}$ Titul začal vycházet v březnu roku 1921 a byl psán německy, čímž cílil především na početnou německy mluvící menšinu a také na zahraniční čtenáře. Kromě obsáhlé zpravodajské části byl opatřen kulturní rubrikou, v níž vycházely například německé překlady z vybraných děl české literatury (Neruda, Čapek), programy divadel, kin či rozhlasového vysílání. V neděli byl vydáván coby př́loha obrazový magazín Bilderbeilage (později přejmenován na Welt am Sonntag) o čtyřech stranách. Noviny byly zastaveny 31 . prosince $1938 .^{8}$

Knihovna Národního muzea vlastní jako jedna z mála institucí v České republice úplnou řadu tohoto periodika včetně jeho nedělních obrazových př́loh, a proto byl titul vybrán k ochrannému reformátování jako první. Dalšími knihovnami jsou např́íklad Národní knihovna, Parlamentní knihovna či Archiv hlavního města Prahy. První dvě zmíněné se posléze podílely na doplňování chybějících čísel z fondu KNM a to nejen pro titul Prager Presse.

Zásadním faktorem pro výběr titulu byla badatelská poptávka a stav degradujícího novinového papíru. Oba tyto faktory spolu stojí v přímé úměře, a čím je titul žádanější, tím rychleji se zhoršuje jeho fyzický stav. Prager Presse, respektive novinový papír, na němž byl tištěn, totiž po téměř sto letech od začátku vydávání sahá po mezi své životnosti. Obzvláště poškozený byl papír z 20. let, což je jev projevující se i u jiných novinových titulů z téže doby. Při listování tak nebylo bohužel žádnou vzácností, že se při pokusu o otočení stránky ulamovaly kousky rohů nebo že se při manipulaci svazkem sypaly závěje dřevito-papírové drti. Př́iprava před digitalizací probíhala několik měsíců a sestávala se převážně z počítání stran, evidence chybějících čísel a posouzení fyzického stavu. Dva hlavní úkoly, které tak digitalizace historického denního tisku plní, je záchrana alespoň digitálního obrazu a také zpřístupnění digitální kopie široké badatelské veřejnosti.

$\mathrm{V}$ prvním roce digitalizace se projekt těšil poměrné finanční hojnosti a současně prríznivé shodě okolností při výběru dodavatele. V prvním kole výběrového řízení se totiž úspěšný uchazeč - firma Scanservice - prrihlásil s cenou, která dosahovala pouze 47 \% celkových očekávaných nákladů. Neupotřebenou část financí bylo následně možno využít k vypsání druhého výběrového rrízení a pokračování digitalizace a dále na pořízení nekyselých obalů.

Díky druhé soutěži, kterou vyhrála firma Exon z Plzně, výrazně vzrostl počet stran, jež se v tomto roce podařilo digitalizovat. Oproti plánu, který počítal s přibližně 26000 stranami, se jich v roce 2016 celkově povedlo digitalizovat více než 47 000. Do digitální knihovny Kramerius tak mohly být naimportovány a badatelské veřejnosti zpř́stupněny nejen ročníky 1921-1926, ale též 1927-1930. Digitalizované svazky byly poté zabaleny do nekyselých krabic, jejich půjčování badatelům zastaveno a byly převezeny do klimatizované místnosti v depozitáři oddělení časopisů v Terezíně.

Z technologického pohledu probíhalo skenování jednodušeji než dř́ve. Tituly Politik a Correspondenz byly v době digitalizace, jak již bylo řečeno výše, nejprve nasnímány na archivní mikrofilmy, z nichž byl obraz až poté převeden do digitální podoby. Originální předloha Prager Presse se však již skenovala plnobarevně př́mo skenerem. Ke snímkům pořízeným na pracovištích obou dodavatelů se přidaly i nižší desítky skenů těch vydání, jež ve exemplárích Knihovny Národního muzea chyběla. Ta dodala z vlastního fondu Národní knihovna a o jejich zakomponování do logické struktury se postaraly firmy, jež k tomu účelu vlastní specializovaný software.

Protože přidělená dotace nepostačovala na digitalizaci celé řady periodika najednou, pokračovalo zpracování do roku 2018. Každý rok bylo digitalizováno přibližně 21000 stran a stálým dodavatelem se stala firma Exon, která digitalizaci titulu v roce 2018 dokončila. Celkově bylo zdigitalizováno přibližně 81000 stran, což v digitálních úložištích představuje více než 2,5 TB. Celková cena digitalizace činila přibližně $650000 \mathrm{Kč}$.

\section{Digitální struktura Prager Presse}

Digitální strukturu Prager Presse založila firma Scanservice, která svou zakázku dokončila jako první. Zvolená struktura byla podle pravidel pro digitalizaci periodik formálně správná a stala se základem pro přípravu zakázek na Prager Presse do dalších let. Přesto se tato struktura posléze ukázala jako ne zcela optimální.

Hned první problém způsobila koordinace přidělování identifikátorů (uuid) v logické struktuře periodika. Identifikátory uuid mají jednoznačně odkazovat na různé úrovně dokumentu a současně slouží jako vodítko pro přiřazování nově importovaných dat do digitální knihovny $\mathrm{k}$ datům stávajícím. Pro periodika se identifikátory přidělují na úroveň stránky, čísla, ročníku a celého titulu.

$\mathrm{V}$ roce 2016 nastala situace, $\mathrm{kdy}$ se digitalizace dvou ročníků Prager Presse (1921 a 1926) rozdělila mezi dvě firmy. Ač si obě firmy pohlídaly identifikátor na úrovni titulu, přidělování identifikátorů pro oba ročníky bylo nekoordinované. Po importu dat od obou firem do Krameria se tak všechna digitální vydání z obou ročníků nesloučila pod jeden ročník (tzv. se nesešla ve společné záložce), čímž začal náročný proces několikerých reklamací a oprav.

Další problém představovaly nedělní obrazové př́lohy Bilderbeilage. Ty pro každý ročník vytvořily vlastní zálož$\mathrm{ku}^{9}$ a jsou tak odděleny od hlavních a večerních vydání. ${ }^{10}$ Nepraktičnost této formálně správné struktury byla zjištěna až později po konzultacích s Národní knihovnou, jež si data po převzetí sama upravila.

\footnotetext{
${ }^{7}$ BEDNAŘÍK - JIRÁK - KÖPPLOVÁ 2011, s. 161.

${ }^{8}$ Dostupné z: https://kramerius.nm.cz/uuid/uuid:90fca8eb-8f4a-11e9-8789-001b63bd97ba [cit. 2. 11. 2021].

${ }^{9}$ Př́lohy Bilderbeilage z roku 1921: https://kramerius.nm.cz/uuid/uuid:243121fa-d6f9-4705-a18f-1ac8f5e2ed03 [cit. 2. 11. 2021].

${ }^{10}$ Ranní a večerní vydání z roku 1921: https://kramerius.nm.cz/uuid/uuid:2f3d6801-946b-415b-9aa3-912706d19fd8 [cit. 2. 11. 2021].
} 
Po dlouhé úvaze se KNM ve vlastních datech rozhodla strukturu s Bilderbeilage ponechat takto majíc na mysli knihovnické pravidlo , i když špatně, aspoň všechno stejně“.

Dlužno říci, že po těchto počátečních nesnázích pokračovala digitalizace Prager Presse v dalších letech sice pomaleji, ale zato méně živelně a koordinovaněji.

\section{Digitalizace titulu Rudé právo}

Již před dokončením Prager Presse byl vytipován další titul k digitalizaci. Zvoleno bylo prvorepublikové Rudé právo a jeho o něco později vzniklé večerní vydání s názvem Rudý večernik. Oba tituly se těší značné badatelské oblibě, přičemž stupeň degradace papíru, na němž byly tištěny, je podobný jako u všech novin z této doby.

Stranický deník Rudé právo vznikl odštěpením od jiného stranického titulu, Práva lidu. ${ }^{11}$ Č́stečně napodoboval jeho obsahovou i grafickou podobu, např́klad tím, že oba tituly vydávaly nedělní přílohu Dělnická besídka. Titul, krom ostrých útoků na všechny politické oponenty, komentoval ze své specifické pozice dění v Československu, přinášel informace o domácím a zahraničním dění, přičemž obzvláštní pozornost věnoval událostem v Sovětském svazu. Dále referoval o sociálních otázkách a díky svému rozšíření se stal nezanedbatelným účastníkem vnitropolitické diskuse. Nezanedbatelnou rubrikou byla i ta kulturní, do níž přispívaly levicově smýšlející osobnosti (např. Marie Majerová, Ivan Olbracht). Redakcí prošla řada osobností, které se po únorovém převratu v roce 1948 dostaly bud' do vysokých mocenských pozic (Antonín Zápotocký, Václav Kopecký, Ladislav Štoll), či naopak byly komunistickým režimem zavrženy (levicový intelektuál Záviš Kalandra). Zastaven byl spolu s jinými komunistickými listy v roce $1938 .{ }^{12}$

At' už se jednalo o pevnost přesvědčení, či o provokace, titul byl kvůli své útočnosti několikrát zastaven či jeho náklad zabavován. Tato skutečnost se negativně odráží na úplnosti jeho dochování ve fondech knihoven, což je fakt, se kterým bylo nutné při přípravě před digitalizací počítat. Oddělení časopisů vyvinulo maximální úsilí při získávání chybějících čísel. Část z nich se podařilo nalézt ve fondech bývalého Muzea dělnického hnutí (dnes ve fondech Národního muzea), část poskytla Národní knihovna a část Parlamentní knihovna, z níž zvláštní poděkování patři panu Janu Komárkovi za obětavou pomoc.

Obzvláště při spolupráci s druhou jmenovanou knihovnou byly učiněny pozoruhodné nálezy. Našly se zde např́iklad výtisky, kterých se kvůli zabavování nákladů zachovalo jen velmi málo. Existence těchto exemplářu chybějících v číselné řadě ve fondu oddělení časopisů nebyla oficiálně potvrzena ani v Národní knihovně, a tvoří tak unikátní nálezy. Odpověd' na otázku, jakou cestou se tedy tyto exempláře do fondů Parlamentní knihovny dostaly, již překračuje rámec tohoto článku a patří spíše badatelské veřejnosti. ${ }^{13}$

Jiný unikátní nález představovaly exempláře z bývalého Muzea dělnického hnutí. Spíše náhodou se v něm nalezly svázané předcenzurní výtisky Rudého večerníku, které oddělení časopisů nevlastní. Jedná se o exempláře, jež měly projít předcenzurní kontrolou ještě předtím, než měl být celý náklad vytištěn a distribuován. Charakterizují je zásahy cenzorovy ruky, jež barevnou pastelkou označovala v článcích ty části, které musely být vypuštěny či přesázeny, a do distribuce se tak dostávala okleštěná podoba jednotlivých vydání. Pro doplňování chybějících čísel v digitalizaci tak byl tento nález velmi vítanou pomocí.

Tato nalezená a digitalizovaná čísla jsou nyní jednotlivě roztroušená v řadě ročníků a výrazně pomohla zaplnit mezery v knihovním fondu. ${ }^{14}$

Specifikem Rudého práva je, že s výjimkou druhé světové války oficiálně vycházelo od roku 1920 až do roku 1995. Digitalizaci ročníků poválečného Rudého práva obstaraly již dř́ve jiné instituce (např. Ústav pro českou literaturu AV $\mathrm{CL}^{15}$ ) a současně již bylo zpř́istupněno v digitální knihovně Kramerius Národní knihovny. ${ }^{16}$ Bylo tedy oč se opř́it při zpracovávání žádosti o dotaci a zájem ze strany Národní knihovny na tzv. „dokončení začátku“ byl značný.

$\mathrm{S}$ digitalizací bylo započato $\mathrm{v}$ roce 2018 a v roce 2020 byly digitalizovány a zveřejněny poslední předválečné ročníky, nyní je tedy v Krameriu Národního muzea vystaveno Rudé právo v rozsahu 1920-1938. ${ }^{17}$ Díky výše popsanému poměrně intenzivnímu doplňování chybějících unikátních exemplářů $\mathrm{z}$ několika různých knihoven a fondu bývalého Muzea dělnického hnutí se můžeme odvážit tvrdit, že jde o nejúplnější veřejně přístupný komplet tohoto titulu, ve srovnání s těmi, které se nacházejí ve fyzické podobě v jiných knihovnách v České republice.

\section{Digitální knihovna Kramerius}

Ani po nabytí nutného minima znalostí se nepodařilo odstranit nedostatky u titulu Prager Presse z prvního roku digitalizace. Důvod spočivá ve výše zmíněných problémech technické povahy a také ve faktu, že v roce 2017 byla správa digitální knihovny načas zcela přerušena. Národní muzeum tehdy vypovědělo smlouvu se společností Unidata, která pro Národní muzeum Krameria spravovala, a za nástupce nebyl bezprostředně nikdo určen. Trvalo několik měsíců, než se části základních úkolů ujali pracovníci z projektu Nový fonograf vedeného Filipem Šírem. K plnohodnotnému obnovení správy došlo až v první polovině roku 2019, kdy byla podepsána smlouva se společností Inovatika, jež začala zajišt'ovat základní servis ke Krameriovi a rovněž plnit i některé nadstandardní úkoly. Nic z toho nemuselo být badateli přistupujícímu

\footnotetext{
${ }^{11}$ BEDNAŘÍK - JIRÁK - KÖPPLOVÁ 2011, s. 169.

${ }^{12}$ Tamtéž, s. 194.

${ }^{13}$ Jedná se např́klad o tento exemplář: https://kramerius.nm.cz/uuid/uuid:ae3635ed-5dee-458f-b50e-859d76b644c5 [cit. 3. 11. 2021].

${ }^{14}$ Např́íklad zde: https://kramerius.nm.cz/uuid/uuid:cfc106e2-98ea-4f74-b8c3-42e359610976 [cit. 3. 11. 2021 ].

${ }^{15}$ Digitální archiv Rudého práva pro roky 1950-1989 je volně dostupný zde: http://archiv.ucl.cas.cz/index.php?path=RudePravo [cit. 3. 11. 2021].

${ }^{16}$ Dostupné zde: https://ndk.cz/uuid/uuid:4eac74b0-e92c-11dc-9fa1-000d606f5dc6 [cit. 3. 11. 2021].

${ }^{17}$ Dostupné zde: https://kramerius.nm.cz/unid/uuid:4eac74b0-e92c-11dc-9fa1-000d606f5dc6 [cit. 3. 11. 2021].
} 
do Krameria zvenčí zřejmé, protože Kramerius fungoval dále i bez zásahů správce. Přerušení správy však zbrzdilo proces nezbytných oprav a např́klad importní duplicity a multiplicity se do roku 2020 nepodařilo odstranit. ${ }^{18}$

Se spuštěním projektu Nový fonograf začaly být pro Krameria vyvíjeny standardy a prostředí, díky nimž by se daly přehrávat zvukové nahrávky. Na konci roku 2017 bylo také rozhodnuto přejít na nejnovější verzi 5.5.0., někdy nesprávně nazývanou „nový Kramerius“. Toto nové a uživatelsky přivětivější rozhraní bylo tehdy ještě ve fázi vývoje, nebylo zcela připraveno pro ostré nasazení a zdaleka ne všechny funkcionality byly dopracovány. Během roku 2018 se z oddělení časopisů KNM a Knihovny Náprstkova muzea stala jakási testovací pracoviště, $v$ nichž byly zkoušeny pokroky a opravy. Jako druhá v České republice nasadila „,nového Krameria“ do ostrého provozu Moravská zemská knihovna a dlužno říci, že až poté a po provedení všech aktualizací zmizely nedodělky, kterými trpěla první verze tohoto rozhraní.

\section{Výhled do budoucnosti}

V roce 2019 došlo ke změně způsobu financování digitalizačních aktivit pro organizace zřizované Ministerstvem kultury. Ministerstvo kultury vyřadilo organizace, které samo zřizuje a k nimž patř́i i Národní muzeum, z možných př́ijemců dotačních příspěvků z programu VISK 7. Částka, o niž se dříve knihovny a podobné organizace ucházely $\mathrm{v}$ tomto programu, jim začala být převáděna př́mo do rozpočtu. Oddělení časopisů KNM se tato změna dotkla v pozitivním smyslu slova. Jednak došlo k navýšení částky, se kterou při digitalizaci periodik hospodaří, jednak k úpravě termínů pro administrativní úkony. Změna zajistila financování na několik nadcházejících let dopředu, a kromě vyššího finančního objemu získalo Národní muzeum více času na administrativní zpracování projektu v průběhu roku a více času na zpracování samotné zakázky.

V roce 2020 bylo započato s digitalizací nového titulu. Je jím meziválečné České slovo. To svou náročností co do struktury, množství příloh, ale i co do spolupráce s jinými knihovnami při získávání chybějících nebo pro digitalizaci nevhodných svazků představuje zatím největší výzvu. Knihovna Národního muzea se přihlásila k digitalizaci ročníků 1918-1945. Titul však začal vycházet již v roce 1907 a po vzájemné dohodě počáteční ročníky začala digitalizovat Národní knihovna. Podaří-li se titul digitalizovat v celé řadě, půjde o dobrý př́klad kooperace několika knihoven při digitalizaci takto žádaného titulu. Jeho široké zpřístupnění v digitální knihovně Kramerius nesporně usnadní práci badatelům, kteří byli při své práci dosud odkázáni na osobní návštěvu studoven. A v neposlední řadě také přispěje $\mathrm{k}$ záchraně titulu vytištěného na nekvalitním a chátrajícím papíře, což je jeden ze zásadních úkolů digitalizace.

\section{Seznam použité literatury:}

BEDNǍ̌ÍK - JIRÁK - KÖPPLOVÁ 2011: BEDNAŘÍK, Petr - JIRÁK, Jan - KÖPPLOVÁ, Barbara. Dějiny českých médii: od počátku do současnosti. Praha: Grada, 2011.

\section{Elektronické zdroje:}

18 Jahre im Dienste der Republik. Prager Presse 18, 1938, č. 321, s. 1. Dostupné z: https://kramerius.nm.cz/uuid/ uuid:90fca8eb-8f4a-11e9-8789-001b63bd97ba [cit. 3. 11. 2021].

VISK 7. Národni program digitálního zpřistupňování dokumentů ohrožených degradací kyselého papíru Kramerius [online]. Praha: Národní knihovna, [2015]. Dostupné z: https://visk.nkp.cz/visk-7 [cit. 5. 11. 2021].

\author{
Adam Jaško \\ Západočeské muzeum - knihovna \\ Kopeckého sady 2 \\ 30100 Plzeň
}

\footnotetext{
${ }^{18}$ Příklad zde: https://kramerius.nm.cz/view/uuid:cd08bd57-d4d9-441d-b748-21b274aadf51?page=uuid:4f1a5491-3180-11e7-9f51-005056ba013a [cit. 3. 11. 2021].
} 